\title{
10 Is Theology Without Walls workable?
}

\author{
Yes, no, maybe
}

\author{
Peter Feldmeier
}

\section{Yes}

The concept of Theology Without Walls is not only an intriguing project, it's one that already aligns with my theological tendencies. I write as a Roman Catholic theologian who has been fascinated by other religions and the potential value they have in informing my own religious sensibilities. As a religious studies major in college (almost four decades ago), I gained an appreciation for other ways of being religious that were quite different from my own. I allowed myself to be open to the religious other, enough so that I subsequently utilized non-Christian classical texts for spiritual reading, including the Upanishads, the Dao De Jing, and classic Zen texts. Much later, in doctoral studies, I wrote my dissertation on comparing the teachings of the Catholic John of the Cross to the Buddhist Buddhaghosa for the purpose of seeing how Buddhist practices might be incorporated into the Christian life without compromising Christian theology; no small project there.

Since the Second Vatican Council (1962-1965), Catholicism has taken a respectful stance toward the religious other, even proclaiming that, through the grace of God, God's saving presence was active in other religious traditions. In no way was this imagined to be some version of relativism. The Church was clear: although God was present and active in other traditions, nonetheless "she proclaims and is in duty bound to proclaim without fail, Christ who is the way, the truth and the life. In him, in whom God reconciled all things to himself, men find the fullness of their religious life" (Nostra Aetate, \#2).

In the theological discipline of theology of religions, this position became known as inclusivism. Here one's home religion is believed to be absolutely true, even while recognizing God's presence in the religious other. There is a kind of imperialism in inclusivism, as other religions are not imagined to be on par with one's own. Vatican II saw the truths articulated in others as "a preparation for the Gospel" (Lumen Gentium, \#16). One of the great liabilities in the inclusivism position is that it tends to look for and affirm those qualities in other religious traditions that look like one's own. If one 
has the fullness of truth, then the religious other could only have partial truths, something that reflects one's own whole truth. It is difficult for the inclusivist to see any unique quality in the religious other, something valuable in its own right.

Since Vatican II, the Catholic Church has added something of a wrinkle in its promotion to dialogue with other religions. In 1984, the Vatican's Pontifical Council for Interreligious Dialogue published a document titled The Attitude of the Church toward Other Religions. Here it outlined various forms of dialogue. These were 1) Dialogue of Life, focusing on common humanity; 2) Dialogue of Collaboration, focusing on humanitarian issues; 3) Theological Dialogue, seeking greater mutual understanding; and 4) Dialogue of Religious Experience, including sharing one's spiritual life and religious practices. Dialogue here is described as "not only discussion, but also includes all positive and constructive relations with individuals and communities of other faiths which are directed at mutual understanding and enrichment" (\#3). The religious other is presumed to have spiritual truths or insights that the Church can learn from. The document goes on to say that "a person discovers that he does not possess the truth in a perfect and total way but can walk together with others toward that goal. Mutual affirmation, reciprocal correction, and fraternal exchange lead the partners in dialogue to a greater maturity." It is an engagement with other religious faiths for "mutual enrichment" (\#21). The text concludes that there may be great differences between various religions, but " $t \mathrm{t}]$ he sometimes profound differences between faiths do not prevent this dialogue. Those differences, rather, must be referred back in humility and confidence to God who 'is greater than our heart' (1 Jn 3:20)" (\#35).

This document became for some Catholic theologians a game-changer. It seems to argue that both the non-Christian tradition and Christianity can be reciprocally corrected, that non-Christian insights can lead the Christian toward a greater maturity, and that both traditions can be mutually enriched by his encounter. Thus, the non-Christian tradition has religious goods the Church does not. Further, where there are differences, the document appeals to God who transcends what our hearts (or minds) can imagine.

While secure in one's primary faith commitments, seeking insights through mutual learning is nothing new to some expressions of Catholicism, even at the formal level. Already in 1974 the Federation of Asian Bishops' Conference in Taiwan declared,

How then can we not give them [the other religions] reverence and honor? And how can we not acknowledge that God has drawn all peoples to Himself through them? ... The great religions of Asia with their respective creeds, cults and codes reveal to us diverse ways of responding to God whose Spirit is active in all peoples and cultures. ${ }^{1}$

Theologians have taken up this call as well. The renowned David Tracy announced three decades ago that "[w]e are fast approaching the day when 
it will not be possible to attempt a Christian systematic theology except in serious conversation with the other great ways" (Tracy 1990, xi). Tracy's insight has borne fruit in what is known as comparative theology. Comparative theologians attempt to do systematic theology in light of dialogue with other religious traditions. Here one engages the texts, theologies, practices, and religious imagination of another religious tradition. This encounter gives one insight from a broader religious context to do Christian theology. Not only does such a procedure widen one's theological imagination, it also facilitates a more authentic sympathy for the religious other. What is attempted by comparative theology is not a syncretistic unification of all religions, but rather a fresh set of eyes and resources to rethink one's own tradition in new ways.

Let me provide a couple of examples of how this might work. Consider Jesus's parable in Luke 18 of two men who went to the temple to pray. One was a Pharisee and the other a tax collector.

The Pharisee, standing by himself, was praying thus, "God, I thank you that I am not like other people: thieves, rogues, adulterers, or even like this tax collector. I fast twice a week; I give a tenth of all my income." But the tax collector, standing far off, would not even look up to heaven, but was beating his breast and saying, "God, be merciful to me, a sinner!" I tell you, this man went down to his home justified rather than the other; for all who exalt themselves will be humbled, but all who humble themselves will be exalted.

Jesus's point is obvious: do not be self-righteous or judgmental but humble, as this is the truly authentic religious posture before God and others. Let us, however, consider this parable through the lens of Buddhism. According to Buddhism, all unskillful thinking, particularly that which inflates the ego, is an expression of delusion and suffering. And the fact that the Pharisee does not see this demonstrates just how unaware he is of the situation. He is suffering but does not know it. Let us take this a further step: almost certainly most readers (you and I) have found ourselves in disdain of the Pharisee (I hate people like that!). Ironically, we are tempted to judge the judgmental Pharisee and take on his same toxic mental state. Buddhist wisdom guides us away from such tendencies with its incisive assessment of how a conditioned mind works and how to become free from such unskillful, conditioned reactivity. One last step: Buddhist wisdom neither condemns the Pharisee nor us, but instead invites us to see how delusion and suffering work in the psyche. Buddhist wisdom allows one to embrace the parable more fully and to cultivate compassion toward all who suffer - the Pharisee, the tax collector, and oneself alike. In short, listening to Buddhism can help us understand our own religious predicament more clearly, and this without compromising our own religious faith.

Let us consider an additional example. In Daoism, there is something known as the Wu-forms. $W u$ is a Chinese negative that is often used as a 


\section{Peter Feldmeier}

prefix. Wu-wei (no-action) refers to the value of nonimposing activity. One does not force something, but instead learns to work with the possibilities at hand. Wu-zhi (no-knowing) refers to letting go of any artificial constructs that would blind one from the uniqueness of the new moment. Wu-yu (nodesire) refers to letting go of one's neurotic need to be attached to some static agenda. In Daoism, the universe is an evolving mystery unfolding before one. The best experience is to participate in it as it is. The $w u$-forms dispose the soul to embrace life as art and optimize creative possibilities without trying to manipulate one's experience. The wu-forms can teach one to cultivate an open, spacious mind and heart, respectful of the reality unfolding before one.

A great temptation in pastoral ministry is to impose an agenda on others. Perhaps the congregation is not vibrant at, say, a wedding. The pastor might want to pump up the energy. But all this guarantees is that the minister and congregation are out of sync. Wu-wei suggests entering the energy that exists and working skillfully with it, not against it. Or perhaps the pastor meets a parishioner in crisis. He or she may be uncomfortable with the pain or ambiguity of the situation. The principle of $w u-y u$ can help the pastor to stop seeking a personal agenda and to be present as the suffering person needs one to be present. For the minister, this does not mean that "I must get rid of this pain." One does not come to the situation imagining that its conclusion ought to be joy, surety, or healing. Although these are laudable goals, they are imposed goals. Indeed, someone may need to grieve or be in doubt a long time. One ought not to force anything. In both these cases, insights from religious others can actually help one's own religious sensibilities and even pastoral presence (Feldmeier 2013, 192-197).

Theology Without Walls seems to me the kind of project that can draw on the uniqueness of various traditions and show how, in dialogue, new insights might emerge. If utilized in the earlier sense, Theology Without Walls would take on a kind of post-Vatican II inclusivistic perspective. Here one would have a starting point with a home tradition that seeks to invigorate itself with the myriad of insights available from other religious traditions. They could provide complementary insights that might create a more robust version of one's own tradition or stretch one's traditional boundaries. I see it as potentially a version of comparative theology.

This is not the only way Theology Without Walls might work. It could take on the presuppositions that belong to a more pluralist camp. Some theologians imagine the great religious traditions as proceeding along the same trajectory, fundamentally doing the same thing. These are broadly known as pluralists. Typically, pluralists rely on several reasonable principles. The first is that God as God transcends all conceptuality. Concepts, they argue, are what humans do, how humans think. They exist to help us negotiate the created world. But God radically transcends the world. Thus, any God talk can only correspond to human ways of imagining or making sense of God for us. Pluralists, such as John Hick, Wilfred Cantwell Smith, and Paul Knitter, 
ask, "What's in a name?" If there is one Transcendent Absolute, and if that Absolute transcends conceptuality, then it matters little whether we call that Absolute God, Brahman, Eternal Dao, and so on. Of course, religions do have their uniqueness, they concede. Still, all authentic religions are dealing with the same reality in different ways.

Pluralists also tend to see religions as not only pointing to the same divine Reality, but also looking much like each other. They share many of the same ethical perspectives, and it is uncanny how similar they are in terms of the kinds of transformation they describe, and even what union with God is like according to their various exemplars. In many traditions, the ordinary self seems to get discarded, while the true self finds a kind of oneness or even quasi-identity with the divine. One literally re-centers oneself in God. As Marianne Moyaert notes,

Pluralists are determined to promote real openness, real reciprocity, and real transformation. They argue for a paradigm shift that would enable Christians to move away from their millennia-long insistence on the superiority and finality of their way, whether in its exclusivist or inclusivist version, and to recognize the independent validity of other religions.

(Moyaert 2014, 120)

That other religions are fundamentally doing the same thing allows for a kind of sharing of resources and insights that seem to go far beyond what any other theology of religions could offer, and it is the most likely perspective one would hold for a Theology Without Walls project. If most or all religions are not fundamentally doing the same thing, then one wonders from where one would start, that is, which first principles would ground one's theology and how one might negotiate competing perspectives? Thus, I think that Theology Without Walls could proceed as some form of pluralism.

One must recognize, however, that so far my framing of Theology Without Walls has been contextualized through some form of a theology of religions. Jerry L. Martin, both privately and in conference forums, insists that this is utterly unnecessary. He argues: Why not simply proceed to think theologically, utilizing the vast array of insights from the world's great depositories of wisdom and insight? What is love or compassion? How does one become holy? How ought the Divine Absolute be understood? To attempt to answer such questions, why not draw insights with the widest net possible? Surely, we might want to start with our own natural operating paradigm, be that Christianity or Hinduism, etc., but Theology Without Walls does not need a theology of religions to do this. While acknowledging that everyone comes to texts or teachings with what Gadamer calls pre-understanding, ${ }^{2}$ one could attempt a kind of tabla rasa (clean slate). What is compassion? Let's see what Christians say, what Buddhists say, what Muslims say, and 


\section{Peter Feldmeier}

so on to come up with a larger and more holistic view of it, informed by its many expressions in various traditions. What is holiness? Again, let's consult broadly.

In affirming the possibilities of Theology Without Walls we might also recognize that it commends itself to a larger public. Young and middle-age adults in the United States are increasingly identifying with being a "none," that is, not identifying with a given religious tradition but refusing to selfidentify as either agnostic or atheist. Progressively, Americans are skeptical about exclusive religious claims, decidedly rejecting fundamentalist religious framings and imagining religions as about the same agenda. They also eschew what they think is the typical politicization of religion. ${ }^{3}$ Thus, Theology Without Walls seems to fit the zeitgeist or spirit of the time. Responding to such a spirit, Julius-Kei Kato calls for a "bybridity that makes us members of multiple worlds and citizens of a global world" (Kato 2016, 271).

\section{No}

So far in this chapter, it looks as though Theology Without Walls is not only commendable but perhaps even indispensable if one is going to do credible theology in this globalized and multiple-religious world. But like most things, the issue is far more complicated. Inclusivist theologians recognize that their home religion really does take priority. The point of interreligious dialogue from an inclusivist framework is to appreciate and revere the religious other and in small ways to allow one's own tradition to be challenged. But here all religions are assuredly not equal. In responding to what was considered overreach by some theologians, the Vatican's Congregation for the Doctrine of the Faith reacted strongly with its publication of Dominus Iesus: On the Unicity and Salvific Universality of Jesus Christ and the Church. Written by Cardinal Joseph Ratzinger, who later became Pope Benedict XVI, Dominus Iesus insisted:

What hinders understanding and acceptance of the revealed truth: the conviction of the elusiveness and inexpressibility of divine truth . . . relativistic attitudes toward truth itself ... the metaphysical emptying of the historical incarnation of the Eternal Logos, reduced to a mere appearing of God in history; the eclecticism of those who, in theological research, uncritically absorb ideas from a variety of philosophical and theological contexts without regard for consistency, systematic connection, or compatibility with truth.

Dominus Iesus concedes that there may be some elements of truth in other religions, but "[i]t is also certain that objectively speaking, they are in a gravely deficient situation in comparison with those who, in the Church, have the fullness of the means of salvation” (\#22). 
The great concern that Ratzinger had was a kind of theological free-forall that neither recognized the priority of the Christian gospel, nor respected the complexity of trying to incorporate insights from other traditions without concern for philosophical or theological consistency. I hope that my example of Daoist insights was helpful to see how comparative work can yield fruitful results. I am also aware, however, that there are massive complexities in making any theological claims that include Daoism. Daoism has its own particular metaphysics that contrasts strongly with Western notions of God. Daoism is virtually acosmic, with no sense that there is an absolute, eternal Reality undergirding created reality. The Dao is not God in any sense; there is no God exactly, but only the ceaseless flow of life. There is no Transcendent Absolute, and thus to draw on its metaphysics is to risk violating the principle of noncontradiction - they can't be both true. And where a Daoist concept depends on such a metaphysic, there will be serious problems incorporating such a concept into a theistic view.

This is one of the biggest concerns I have for Theology Without Walls: its scope seems to be simply too large. What the most responsible comparative theologians do is relatively small and discrete. Francis Clooney, the foremost authority in comparative theology, is a good example. He has spent his career comparing Hindu insights with Christian ones. In every attempt, his scope is highly circumscribed. Clooney writes,

[T] he opportunities present in the interreligious situation are most fruitfully appropriated slowly and by way of small and specific examples taken seriously and argued through in their details. . . . Interreligious theology is not the domain of generalists but rather of those willing to engage in detailed study, tentatively and over time.

(Clooney 2001, 164)

Further, his work is intended to both stretch and be faithful to his own faith (i.e., Christianity). In commenting on comparative theologians, Michael Barnes notes that they favor "experiments, focused micro-studies that acknowledge the freedom of the Spirit while at the same time driving the faithful thinker deeper into the mystery of the divine encounter as it is inscribed in ... the home tradition" (Barnes 2016, 241).

Pluralism is not without its own method problems. Critics have observed that pluralists tend to home in on what appears similar in different religions without taking seriously the differences. They tend to look for evidence from an already predetermined pluralist assumption, something of a conclusion looking for supportive data. I noted earlier that witnesses of mystical union look very much alike among various religions. But others have argued that if you looked carefully, the similarities fade in light of the particularities of each religion. A scholar of mysticism, Stephen Katz, has argued that the past two decades of research have now rejected the earlier assumptions that mystics were having the same experiences. These assumptions, he states, 


\section{Peter Feldmeier}

are "simplistic and untrue to the data at hand" (Katz 2013, 5). According to Katz and others, Muslims have Islamic mystical experiences, Jews have Jewish experiences, Buddhists have Buddhist experiences, and so on (Katz 2013, 5-6).

Not only have pluralists potentially overshot their mark on any unifying qualities in the world's religions, they can tend to undermine their own home religion in striving for universal claims. In a friendly debate between myself and Paul Knitter, we discussed whether Buddhism and Christianity were commensurable, that is, able to be aligned. I charged Knitter with downgrading God (from a Christian point of view) and eternalizing creation. I also charged him with misappropriating classic Buddhist texts. Whether my position succeeded is for the scholarly audience to decide. Regardless, the danger lurks large when striving to see a unified religious world that may not be so unified after all. ${ }^{4}$

This same problem occurs without a theology of religions informing one's assumptions. The quasi-tabla rasa position, discussed earlier, has yet to deal in a satisfying way with the problems of uniting insights from various religions without recognizing that those very insights are tied to structures of thought that can be incommensurable with other structures of thought. Many scholars argue that religions simply cannot be well compared or mutually drawn on. In George Lindbeck's influential book, The Nature of Doctrine, he argues that religions resemble languages that are intrinsically unique and inseparable from their respective cultures. Lindbeck writes,

Adherents of different religions do not diversely thematize the same experience, rather they have different experiences. Buddhist compassion, Christian love and ... French revolutionary fraternité are not diverse modifications of a single human awareness, emotion, attitude, or sentiment, but are radically (i.e., from the root) distinct ways of experiencing and being oriented toward self, neighbor, and cosmos.

(Lindbeck 1984, 40, as cited in

Moyaert 2014, 131)

Moyaert notes that "according to Lindbeck, there is still a second reason why religions are untranslatable. Religions are all-encompassing interpretive schemas." Thus, citing Lindbeck, "nothing can be translated out of the idiom into some supposedly independent communicative system without perversion, diminution or incoherence of meaning" (Moyaert 2014, 131). In short, trying to incorporate Nirvana into some Christian interpretive scheme is certain to undermine what Buddhists really mean by Nirvana, as well as to compromise Christianity, which simply has no message regarding Nirvana or interest in it. We might call Lindbeck the herald of a new kind of theology of religions, that is, the postliberal or postmodern position. In short, it proclaims that there can be no meta-narrative, no absolute vision or paradigm that could absorb or account for everything. 
A final potential problem with a Theology Without Walls has to do with its readership. I noted earlier that this is the kind of project that would appeal particularly to the nones, those who reject particular or exclusive claims from religion but are open to larger universal claims. The problem is that this is less a community than it is an audience. Centuries ago, the great Christian theologian Anselm of Canterbury famously defined theology as fides quaerens intellectum - faith seeking understanding. What any theology requires, including Theology Without Walls, is a living faith. Faith is the condition of possibility for theology to make sense, to be valuable. I wonder if Theology Without Walls would actually help this audience or if it would encourage its readership away from a particular faith. I see religions as forums for spiritual transformation. I also see religions as having their own particularities and unique expressions of this transformation. Religions operate as paradigms or lenses of interpretation of experience. Their respective dogmas act like fences within which its members live. Such fences could be permeable, even climbable, but they seem to be necessary. They give religion form. Could Theology Without Walls be ultimately formless?

\section{Conclusion: maybe}

Some scholars, including me, believe that all the earlier positions and those of their critics can be overstated. Inclusivism rightly insists that if one thinks one's religion is true - really true - then this has consequences as to what one thinks of alternative faiths. But inclusivism cannot account for authentic and very different religious expressions that do not fit well into its own religious tradition. If the Catholic Church, for example, takes on the inclusivist model, it does so without consistency. If one can really learn from the religious other, then one's tradition cannot have all the goods. Pluralism rightly sees universal tendencies that make interreligious sharing possible. I am not at all convinced that other religions are so incommensurable as Lindbeck insists. There really are massive similarities that make interreligious sharing possible. On the other hand, pluralism does underestimate religious differences. And although the postmodern position is right to warn against colonizing the religious other, it overstates its own position. If religions are different languages, we can learn these languages and see cognates in our own. Further, there is no pure religion that has not been influenced by forces outside itself. For example, early Christianity was decidedly influenced by Neoplatonism. Thomas Aquinas, the great medieval synthesizer, unabashedly drew on Aristotle, Plato, and Islamic and Jewish sources such as Avicenna and Maimonides.

Thus, I see Theology Without Walls as valuable and in some ways already being done fruitfully. But I must ask, what would it look like in its most robust expression? By what method? Would it have a theological foundation, say, Christianity, and then extend this to include insights from the world's religions? Or would it start from scratch and attempt a unified 


\section{Peter Feldmeier}

theory of religion? How would it address philosophical positions that have very different and even colliding first principles? These are the questions that would have to be answered. If successfully addressed and defended, then - maybe!

\section{Notes}

1 Cited in Chia $(2016,49)$.

2 See Gadamer $(1975,274-289)$.

3 See Putman and Campbell (2010), passim.

4 This debate initially took place at the Catholic Theological Society of America in 2015 and subsequently published as Knitter and Feldmeier (2016).

\section{References}

Barnes, Michael. 2016. "The Promise of Comparative Theology: Reading between the Lines." In Interfaith Dialogue: Pathways for Ecumenical and Interreligious Dialogue, edited by Edmund Kee-Fook Chia, 237-250. New York: Palgrave Macmillan.

Chia, Edmund Kee-Fook. 2016. "Response of the Asian Church to Nostra Aetate." In Interfaith Dialogue: Pathways for Ecumenical and Interreligious Dialogue, edited by Edmund Kee-Fook Chia, 45-56. New York: Palgrave. doi:10.1057/978-1-137-59698-7_4

Clooney, Francis X. 2001. Hindu God, Christian God: How Reason Helps Break Down the Boundaries between Religions. Oxford: Oxford University Press. doi:10.1086/382319

Feldmeier, Peter. 2013. "Christian Transformation and the Encounter with the World's Holy Canons.” Horizons 40 (2): 192-197. doi:10.1017/hor.2013.72

Gadamer, Hans-Georg. 1975. Truth and Method. Trans. Garrett Barden and John Cummings. New York: Seabury Press.

Kato, Julius-Kei. 2016. "Epistemic Confidence, Humility, and Kenosis in Interfaith Dialogue." In Interfaith Dialogue: Pathways for Ecumenical and Interreligious Dialogue, edited by Edmund Kee-Fook Chia, 265-276. New York: Palgrave Macmillan. doi:10.1057/978-1-137-59698-7_20

Katz, Steven. 2013. "Introduction.” In Comparative Mysticism: An Anthology of Original Sources, edited by Steven Katz, 3-22. Oxford: Oxford University Press.

Knitter, Paul, and Peter Feldmeier. 2016. "Are Buddhism and Christianity Commensurable? A Debate/Dialogue Between Paul Knitter and Peter Feldmeier." Journal of Buddhist-Christian Studies 36 (1): 165-184. doi:10.1353/bcs.2016.0015

Lindbeck, George. 1984. The Nature of Doctrine: Religion and Theology in a Postliberal Age. Philadelphia: Westminster Press. doi:10.1177/004057368504200214

Moyaert, Marianne. 2014. In Response to the Religious Other: Ricoeur and the Fragility of Interreligious Encounters. Lanham: Lexington Books.

Putman, Robert, and David Campbell. 2010. American Grace: How Religion Divides and Unites Us. New York: Simon \& Schuster. doi:10.1017/s0022381612000771

Tracy, David. 1990. Dialogue with the Other: The Inter-Religious Dialogue. Louvain: Peeters. 